\title{
WORK ACCIDENTS IN THE BRAZILIAN FOREST SECTOR
}

\author{
Juliana Gomes Messiah Viegas ${ }^{1 *}$, Luís Carlos de Freitas ${ }^{1}$, Rodrigo Pereira Santos ${ }^{2}$, Ângelo Márcio Pinto Leite ${ }^{3}$, \\ Nilton César Fiedler ${ }^{4}$ \\ ${ }^{1}$ State University of Southwestern Bahia, Graduate Program in Forestry Sciences, Vitória da Conquista, Bahia, Brazil, \\ *julianamessias@ifba.edu.br, luisfreitas@uesb.edu.br \\ ${ }^{2}$ State University of Southwestern Bahia, Vitória da Conquista, Bahia, Brazil, admrodrigopsantos@gmail.com \\ ${ }^{3}$ Federal University of Jequitinhonha and Mucuri Valleys, Department of Forestry Engeneering, Diamantina, Minas Gerais, Brazil, \\ ampleite@ig.com.br; \\ ${ }^{4}$ Federal University of Espírito Santo, Department of Forestry Engineering, Jerônimo Monteiro, Espírito Santo, Brazil, fiedler@ pq.cnpq.br
}

Received for publication: 01/03/2017 - Accepted for publication: 17/10/2017

\begin{abstract}
This research aimed to evaluate occurrences of work accidents in the Brazilian forest sector involving activities of production of planted and natural forests, and forest support from 2010 to 2014 in order to carry out a diagnosis related to the safety and health of the worker. The sources for the data, collected from a literature research, were obtained based on historical data of the Company of Technology and Information from Social Security (DATAPREV). The results revealed that the activities of planted forests had the highest mean of accidents, followed by the forest support activities and the natural forests. States such as Minas Gerais, São Paulo, Paraná, Santa Catarina, Bahia, and Maranhão, for the greater extension in terms of planted forest areas, presented the highest mean of accidents in the sector during the period studied. By the Index Accident of Planted Forest (IAFP), the States of Mato Grosso do Sul, São Paulo, and Bahia had the highest average of occurrence of accidents (1,000 ha/planted forest) and the Minas Gerais state, the lowest one. The incidence rate of accidents in activities of planted forest and forest production support presented a frequency of occurrence higher than the Brazilian national average. The concessions of Social Security benefits for temporary disability (more than 15 days), permanent disability, and death in the forest sector caused to the Social Security an average spending of more than R $\$ 31$ million. We concluded that the work accidents in this sector are significant and give rise to expenditures.

Keywords: Occupational safety; social security; occupational risks.
\end{abstract}

\section{Resumo}

Acidentes ocupacionais no setor florestal brasileiro. Objetivou-se, com esta pesquisa, avaliar as ocorrências de acidentes de trabalho no setor florestal brasileiro envolvendo as atividades de produção de floresta plantada, nativa e de apoio florestal no período de 2010 a 2014, com o intuito de realizar um diagnóstico relacionado à segurança e saúde do trabalhador. As fontes para a pesquisa bibliográfica dos dados foram obtidas com base em históricos da Empresa de Tecnologia e Informações da Previdência Social (DATAPREV). Os resultados evidenciaram que as atividades de florestas plantadas tiveram a maior média de acidentes, seguidas das atividades de apoio à produção florestal e de florestas nativas. Os estados de Minas Gerais, São Paulo, Paraná, Santa Catarina, Bahia e Maranhão, pela maior extensão em termos de áreas de florestas plantadas apresentaram a maior média de acidentes no setor no período estudado. Pelo Índice de Acidente de Floresta Plantada (IAFP), os estados do Mato Grosso do Sul, São Paulo e Bahia obtiveram a maior ocorrência média de acidentes para cada 1.000 ha de área plantada e o estado de Minas Gerais, o menor IAFP. A taxa de incidência dos acidentes nas atividades de floresta plantada e apoio à produção florestal apresentou frequência de ocorrência superior à média nacional brasileira. As concessões dos benefícios previdenciários para incapacidade temporária (superior a 15 dias), invalidez permanente e óbito no setor florestal ocasionaram à Previdência uma despesa média superior a R \$ 31 milhões. Concluiu-se que os acidentes de trabalho nesse setor são significativos e ocasionam despesas.

Palavras-chave: Segurança do trabalho; previdência social; riscos ocupacionais.

\section{INTRODUCTION}

Due to the economic importance of the forest sector, Brazil has developed a complex productive structure, especially in relation to forests planted with species of Pinus sp. and Eucalyptus sp. In general terms, if we consider the total forest area, the country has $98.01 \%$ of the natural forests and only $1.99 \%$ of planted forests (SNIF, 2016).

Forestry activity in Brazil has increased in the last few years, becoming attractive for entrepreneurs and investors. However, the economic potential of the country coexists with a high prevalence of fatal work accidents along with numerous risks of accidents in the forest sector (MEDEIROS; JURADOS, 2013).

FLORESTA, Curitiba, PR, v. 47, n.4, p. 561 - 568, out/dez. 2017.

Viegas, J. G. M. et al.

ISSN eletrônico 1982-4688

DOI: $10.5380 /$ rf.v47i4.50954 
Many forest-based companies consider their harvesting activities to be hazardous, which demands more effort from the worker and causes fatigue, discomfort, and health problems. Such issues decrease the worker's concentration, increases the rates of work accidents, and generates loss of productivity, efficiency, and quality in the operation (HECK JUNIOR; OLIVEIRA, 2015).

Work must neither cause damage to health nor generate deaths and sequelae, but rather be a healthy space for appreciation of the worker in order to produce wealth for the country. In this sense, companies urge to adopt actions capable of preventing accidents to comply with current Brazilian legislation.

Richthofen (2006) states that agriculture, livestock, and forestry are sectors of economic activity considered to have high rates of occupational accidents and diseases, although their frequency is not always diagnosed and notified to the authorities. The number of work accidents is high, greater than the number evidenced by statistics. This situation occurs due to the companies' high rate of underreporting and to the lack of workers' issuance of the Occupational Accidents Registry (CAT) in an attempt to omit the reality of their working conditions, for they fear the penalties applied by the supervisory bodies.

Assunção and Câmara (2011) assert that accidents are underreported and, when available, the data are not disaggregated, making it difficult to analyze according to the characteristics of the company, of the operations involved and of the worker profile. By the issuance of CAT, the accident is officially recorded and recognized, establishing the worker's right to the accident insurance to be provided by the National Institution of Social Security (INSS), in case one stays away from work for more than 15 (fifteen) days. However, not all companies register the misfortunes originated in their work environments. Hence, it should be noted that the record of work accidents is an important instrument that provides Social Security, statistical, and epidemiological information that provides a labor and social support to the Brazilian formal worker.

Finally, in order to diagnose issues related to the health and safety of the forest worker, this research aimed to evaluate the occurrences of work accidents in the sector, involving activities of production of planted forest, natural forest, and forest production support activities in the period from 2010 to 2014 .

\section{MATERIAL AND METHODS}

In order to achieve the objectives of this study, we opted to use exploratory and descriptive research, through a bibliographical survey on the subject being studied. To evaluate the occurrence of work accidents in the forest sector, the data base of the Ministry of Social Security - DATAPREV was used to filter the data regarding the (Brazilian) National Classification of Economic Activity (CNAE) of forest production of planted forest (CNAE 02.10-1), forest production of natural forest (CNAE 02.20-9) and forest support activities (CNAE 02.30-6) in Brazil from 2010 to 2014. The statistical data refer to accidents classified as typical, commuting, occupational diseases, and occupational hazards, with issuance of the CAT by the companies, applied by the supervisory bodies. The information was compiled in Excel spreadsheets, and descriptive statistics were used to analyze the data.

In order to carry out a comparative analysis among the work accidents in the studied sector, we calculated the Index of Accidents in Planted Forests (IAFP) for the states with higher concentration of plantations, by the following formula:

$$
\mathrm{IAFP}=\frac{(\text { area for forest plantation on the state }(\mathrm{ha}) / 1000)}{\text { number of accidents of the sector on the state }}
$$

The number of work accidents for every thousand hectares of planted area between the years 2010 to 2014 was considered. The Brazilian Industry of Trees (IBÁ, 2015) subsidized the information from this study regarding the areas of occupation in the states that cultivated eucalyptus and pine, main crops planted in the country.

Another indicator assessed in the research was the incidence rate of work accidents, which evaluates the intensity of the occurrence, expressed by the ratio between the number of new work accidents recorded each year and the average amount of workers exposed to those conditions, according to the following formula:

$$
\text { Incidence rate }=\frac{\text { number of new registered accidents cases }}{\text { mean annual number of bonds }} \times 1000
$$

\section{RESULTS}

According to the Social Security Statistical Yearbook (AEPS, 2016), there were 704,136 accidents in Brazil in 2014. Such number represents a decrease of 3\% compared to 2013, when there were 725,664 accidents 
recorded. AEPS also showed that accidents caused 2,783 deaths throughout 2014, which represents a daily average of seven deaths.

In the forest sector, 2,460 work accidents were recorded in 2014. Compared to 2013, there was a reduction of approximately $13.13 \%$ in the number of accidents. We can observe the index of work accidents in the forest sector in the period from 2010 to 2014 in Figure 1 (AEPS, 2014).
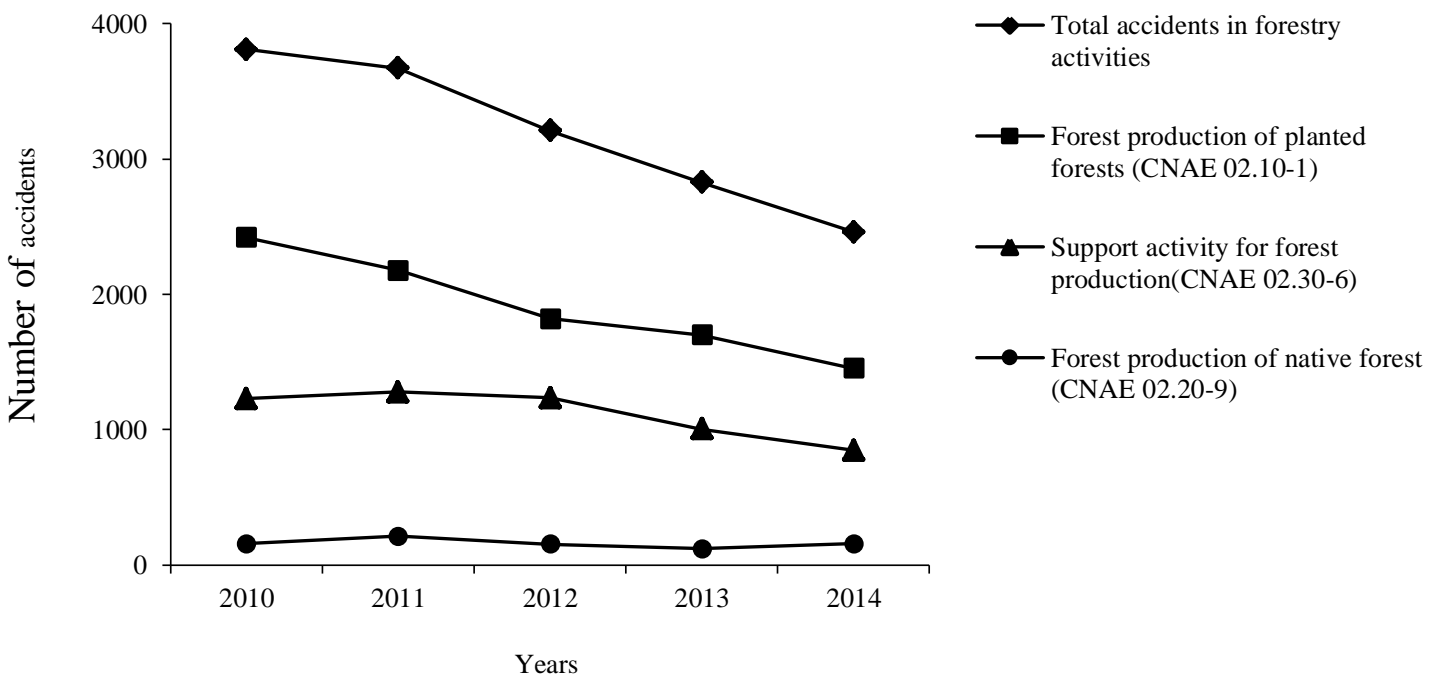

Figure 1. Number of work accidents in the Brazilian forest sector, involving the activities of planted forest, natural forest, and forest support in the period from 2010 to 2014.

Figura 1. Número de acidentes de trabalho no setor florestal do Brasil, envolvendo as atividades de floresta plantada, nativa e apoio florestal no período de 2010 a 2014.

For a better analysis of the forest scenario in Brazil, we presented, in absolute numbers, the history of work accidents registered in the activities of planted forest, natural forest, and forest production support in the period from 2010 to 2014 (Table 1).

Table 1. Number of work accidents registered in Brazilian states by region and in total numbers $(2010-2014)$, regarding activities of planted forest, natural forest, and forest support.

Tabela 1. Número de acidentes de trabalho registrados nos estados, por região e o total no Brasil (2010 - 2014), nas atividades de floresta plantada, nativa e apoio florestal.

\begin{tabular}{|c|c|c|c|c|c|c|c|}
\hline \multirow{2}{*}{ Region } & \multirow{2}{*}{ States } & \multicolumn{6}{|c|}{ Year - Number of Accidents } \\
\hline & & 2010 & 2011 & 2012 & 2013 & 2014 & Mean \\
\hline \multirow{7}{*}{ North } & Acre & 1 & 6 & 1 & 0 & 2 & 2.00 \\
\hline & Amapá & 18 & 33 & 46 & 41 & 21 & 31.80 \\
\hline & Amazonas & 0 & 6 & 7 & 1 & 2 & 3.20 \\
\hline & Pará & 273 & 290 & 223 & 159 & 130 & 215.00 \\
\hline & Rondônia & 25 & 25 & 15 & 15 & 17 & 19.40 \\
\hline & Roraima & 5 & 5 & 6 & 24 & 7 & 9.40 \\
\hline & Tocantins & 9 & 43 & 23 & 25 & 19 & 23.80 \\
\hline \multirow{4}{*}{ Midwest } & Federal District & 1 & 1 & 4 & 2 & 2 & 2.00 \\
\hline & Goiás & 35 & 21 & 28 & 18 & 5 & 21.40 \\
\hline & Mato Grosso & 84 & 75 & 77 & 76 & 116 & 85.60 \\
\hline & Mato Grosso do Sul & 125 & 214 & 129 & 206 & 112 & 157.20 \\
\hline \multirow{9}{*}{ Northeast } & Alagoas & 1 & 1 & 0 & 0 & 1 & 0.60 \\
\hline & Bahia & 225 & 265 & 225 & 249 & 167 & 226.20 \\
\hline & Ceará & 1 & 0 & 1 & 0 & 0 & 0.40 \\
\hline & Maranhão & 236 & 300 & 227 & 181 & 157 & 220.20 \\
\hline & Paraíba & 59 & 44 & 29 & 27 & 37 & 39.20 \\
\hline & Pernambuco & 364 & 150 & 82 & 69 & 74 & 147.80 \\
\hline & Piauí & 10 & 22 & 12 & 11 & 13 & 13.60 \\
\hline & Rio Grande do Norte & 0 & 0 & 0 & 0 & 1 & 0.20 \\
\hline & Sergipe & 3 & 0 & 0 & 1 & 2 & 1.20 \\
\hline
\end{tabular}

FLORESTA, Curitiba, PR, v. 47, n.4, p. 561 - 568, out/dez. 2017.

Viegas, J. G. M. et al.

ISSN eletrônico 1982-4688

DOI: $10.5380 /$ rf.v47i4.50954 


\begin{tabular}{cccccccc}
\hline \multirow{4}{*}{ Southwest } & Espírito Santo & 85 & 105 & 114 & 83 & 92 & 95.80 \\
& Minas Gerais & 882 & 735 & 720 & 599 & 593 & 705.80 \\
& Rio de Janeiro & 9 & 12 & 29 & 21 & 6 & 15.40 \\
& São Paulo & 408 & 423 & 434 & 292 & 275 & 366.40 \\
\hline \multirow{3}{*}{ South } & Paraná & 472 & 406 & 324 & 296 & 270 & 353.60 \\
& Santa Catarina & 267 & 251 & 215 & 212 & 188 & 226.60 \\
& Rio Grande do Sul & 210 & 237 & 239 & 224 & 151 & 212.20 \\
\hline & & 3,808 & 3,670 & 3,210 & 2,832 & 2,460 & $3,196.00$ \\
\hline
\end{tabular}

Source: Ministry of Social Security - DATAPREV.

In table 2, it is possible to visualize the Index Accident of Planted Forest (IAFP) related to the activities of planted forest and forest support in the states with the highest concentration of forest plantations.

Table 2. Index of work accidents $(1,000 \mathrm{ha} /$ planted forest) registered in Brazilian states with the highest concentration of forest plantations.

Tabela 2. Índice dos acidentes de trabalho, para cada 1000/ha de floresta plantada, registrados nos estados do Brasil, com maior concentração de plantios florestais.

\begin{tabular}{cccccccc}
\hline \multirow{2}{*}{ States } & \multicolumn{9}{c}{ Year - IAFP } \\
\cline { 2 - 7 } & $\mathbf{2 0 1 0}$ & $\mathbf{2 0 1 1}$ & $\mathbf{2 0 1 2}$ & $\mathbf{2 0 1 3}$ & $\mathbf{2 0 1 4}$ & Mean \\
\hline Minas Gerais & 1.77 & 2.08 & 2.12 & 2.52 & 2.51 & 2.20 \\
São Paulo & 3.04 & 2.87 & 2.78 & 3.94 & 4.28 & 3.38 \\
Paraná & 1.84 & 2.14 & 2.54 & 2.93 & 3.38 & 2.57 \\
Santa Catarina & 2.45 & 2.62 & 3.05 & 3.10 & 3.52 & 2.95 & 3.07 \\
Bahia & 3.12 & 2.56 & 2.91 & 2.71 & 4.06 & 4.36 \\
Mato Grosso do Sul & 3.29 & 2.31 & 4.94 & 3.54 & 7.72 & 2.29 \\
Espírito Santo & 2.47 & 1.91 & 1.82 & 2.64 & 2.60 & \\
\hline
\end{tabular}

Source: Ministry of Social Security - DATAPREV and IBÁ (2015).

Figure 2 illustrates the incidence rate of work accidents in Brazil in the activities of planted forests, natural forests, forest production support, and the national average that includes all business segments.

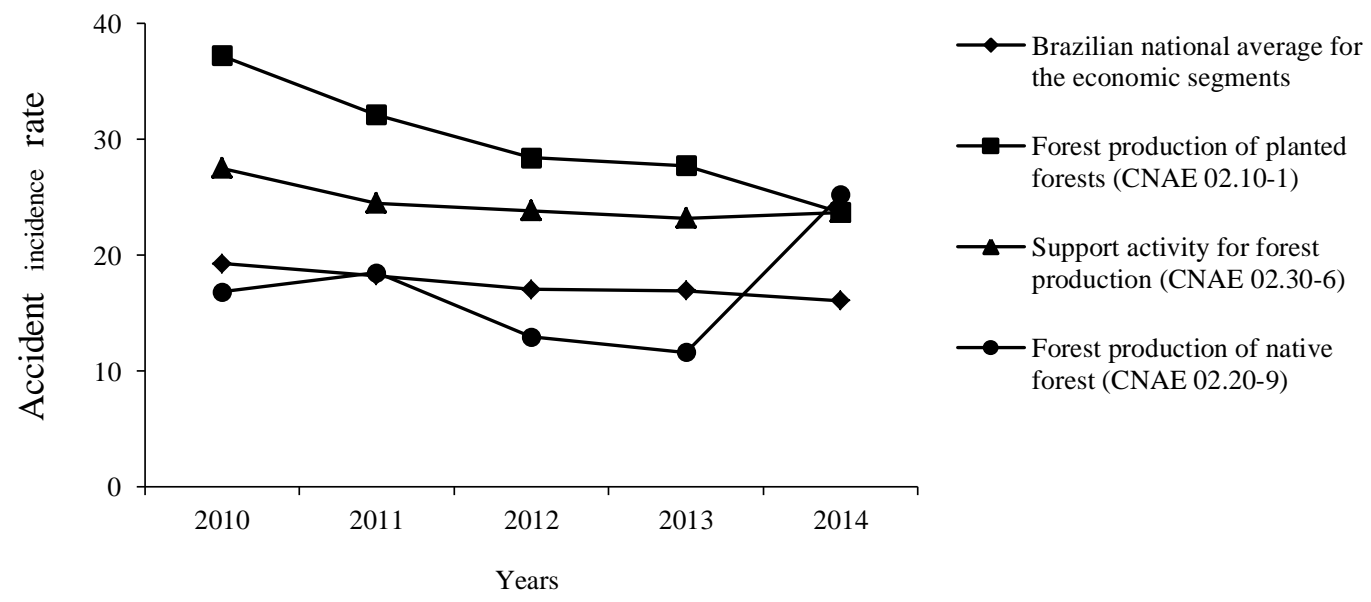

Figure 2. Work accident incidence rate in the activities of planted forests, natural forests, forest support, and other economic segments in Brazil (2010 - 2014).

Figura 2. Taxa de incidência de acidente de trabalho nas atividades de floresta plantada, nativa, apoio florestal e demais segmentos econômicos no Brasil (2010 - 2014).

Considering only the available information in DATAPREV concerning Social Security costs with sick pay (temporary disability for more than 15 days), death benefit, disability retirement, and worker's compensation, we observed that, from 2010 to 2014, an amount of more than R $\$ 43$ billion of expenditure was generated, as illustrated in table 3. 
Table 3. Mean Social Security expenditures, mean granted benefits and estimated cost per accident in Brazil, from 2010 to 2014.

Tabela 3. Média de despesas da Previdência Social, média de benefícios concedidos e estimativa do custo por acidentado no Brasil, no período de 2010 a 2014.

\begin{tabular}{|c|c|c|c|c|c|c|c|}
\hline \multirow{2}{*}{ Year } & \multicolumn{2}{|c|}{$\begin{array}{l}\text { Temporary disability } \\
\text { More than } 15 \text { days }\end{array}$} & \multicolumn{2}{|c|}{ Permanent disability } & \multicolumn{2}{|c|}{ Death } & \multirow{2}{*}{$\begin{array}{c}\text { Total } \\
\text { expenditure }\end{array}$} \\
\hline & Benefit & $\begin{array}{l}\text { Expenditure } \\
\text { (per million) }\end{array}$ & Benefit & $\begin{array}{l}\text { Expenditure } \\
\text { (per million) }\end{array}$ & Benefit & $\begin{array}{l}\text { Expenditure } \\
\text { (per million) }\end{array}$ & \\
\hline 2010 & 309,827 & $\mathrm{R} \$ 3,695$ & 15,942 & $\mathrm{R} \$ 1,850$ & 2,753 & $\mathrm{R} \$ 1,328$ & $\mathrm{R} \$ 6,873$ \\
\hline 2011 & 306,503 & $\mathrm{R} \$ 4,195$ & 16,658 & $\mathrm{R} \$ 2,082$ & 2,938 & $\mathrm{R} \$ 1,393$ & $\mathrm{R} \$ 7,670$ \\
\hline 2012 & 288,063 & $\mathrm{R} \$ 4,571$ & 17,047 & $\mathrm{R} \$ 2,371$ & 2,768 & $\mathrm{R} \$ 1,514$ & $\mathrm{R} \$ 8,456$ \\
\hline 2013 & 271,314 & $\mathrm{R} \$ 5,344$ & 14,837 & $\mathrm{R} \$ 2,656$ & 2,797 & $\mathrm{R} \$ 1,839$ & $\mathrm{R} \$ 9,839$ \\
\hline 2014 & 251,594 & $\mathrm{R} \$ 5,950$ & 13,833 & $\mathrm{R} \$ 2,994$ & 2,783 & $\mathrm{R} \$ 2,033$ & $\mathrm{R} \$ 10,977$ \\
\hline Mean & 285,460 & $\mathrm{R} \$ 4,751$ & 15,663 & $\mathrm{R} \$ 2,390.6$ & 2,808 & $\mathrm{R} \$ 1,621.4$ & $\mathrm{R} \$ 43,815$ \\
\hline $\begin{array}{l}\text { Average cost } \\
\text { per accident }\end{array}$ & \multicolumn{2}{|c|}{$\begin{array}{c}\mathrm{R} \$ 16,643.30 \\
\text { (a) }\end{array}$} & \multicolumn{2}{|c|}{$\begin{array}{c}\mathrm{R} \$ 152,623.31 \\
(\mathbf{b})\end{array}$} & \multicolumn{2}{|c|}{$\begin{array}{c}\mathrm{R} \$ 577,462.78 \\
(\mathbf{c})\end{array}$} & \\
\hline
\end{tabular}

Source: Ministry of Social Security - DATAPREV.

Notes:
(a) = Average cost per temporary disability accident for more than 15 days
(b) = Average cost per permanent disability accident
(c) = Average cost per accident due to death

The estimated value for the average cost that Social Security disburses per accident was obtained by the ratio between the average expenditure and the benefits granted from 2010 to 2014. Thus, we observed how the work accidents are onerous, according to Table 3. The accident due to death, for example, costs more than $\mathrm{R} \$$ 577 thousand per victim.

The representativeness of the financial impact generated by work accidents in the forestry sector on Social Security in the states with the highest number of planted forests is presented in Table 4. The average sick pay (temporary disability for more than 15 days), death benefit, disability retirement, worker's compensation and the expenditures in the studied period were considered.

Table 4. Number of average benefits granted by Social Security, mean value of benefits per category in the forestry sector for the most representative states (period 2010 - 2014).

Tabela 4. Número de benefícios médios concedidos pela Previdência Social, valor médio dos benefícios por categoria no setor florestal para os estados mais representativos (período 2010 - 2014).

\begin{tabular}{|c|c|c|c|c|c|c|c|}
\hline \multirow{2}{*}{ States } & \multicolumn{2}{|c|}{$\begin{array}{l}\text { Temporary disability } \\
\text { More than } 15 \text { days }\end{array}$} & \multicolumn{2}{|c|}{ Permanent disability } & \multicolumn{2}{|c|}{ Death } & \multirow{2}{*}{ Total expenditure } \\
\hline & $\begin{array}{l}\text { Benefit } \\
\text { (d) }\end{array}$ & $\begin{array}{c}\text { Expenditure } \\
(\text { a x d })\end{array}$ & $\begin{array}{c}\text { Benefit } \\
(\mathbf{e})\end{array}$ & $\begin{array}{l}\text { Expenditure } \\
(\text { b x e })\end{array}$ & $\begin{array}{l}\text { Benefit } \\
\text { (f) }\end{array}$ & $\begin{array}{c}\text { Expenditure } \\
(\text { a x d })\end{array}$ & \\
\hline Bahia & 067.6 & $\mathrm{R} \$ 1,125,087$ & 2.8 & $\mathrm{R} \$ 427,345$ & 0.6 & $\mathrm{R} \$ 346,478$ & $\mathrm{R} \$ 1,898,910$ \\
\hline Minas Gerais & 286.0 & $\mathrm{R} \$ 4,759,984$ & 18 & $\mathrm{R} \$ 2,747,220$ & 2.2 & $\mathrm{R} \$ 1,270,418$ & $\mathrm{R} \$ 8,777,622$ \\
\hline Espírito Santo & 016.2 & $\mathrm{R} \$ 4,759,984$ & 1 & $\mathrm{R} \$ 152,623$ & 0.2 & $\mathrm{R} \$ 115,493$ & $\mathrm{R} \$ 5,028,100$ \\
\hline São Paulo & 098.4 & $\mathrm{R} \$ 1,637,701$ & 5 & $\mathrm{R} \$ 763,117$ & 2.4 & $\mathrm{R} \$ 1,385,911$ & $\mathrm{R} \$ 3,786,728$ \\
\hline Paraná & 177.2 & $\mathrm{R} \$ 2,949,193$ & 9.4 & $\mathrm{R} \$ 1,434,659$ & 1.8 & $\mathrm{R} \$ 1,039,433$ & $\mathrm{R} \$ 5,423,285$ \\
\hline Santa Catarina & 146.6 & $\mathrm{R} \$ 2,439,908$ & 15.6 & $\mathrm{R} \$ 2,380,924$ & 1 & $\mathrm{R} \$ 577,463$ & $\mathrm{R} \$ 5,398,294$ \\
\hline Mato Grosso do Sul & 044.6 & $\mathrm{R} \$ 742,291$ & 1 & $\mathrm{R} \$ 152,623$ & 1.2 & $\mathrm{R} \$ 692,955$ & $\mathrm{R} \$ 1,587,870$ \\
\hline
\end{tabular}

Source: Ministry of Social Security - DATAPREV.

Notes:

(a) = Average cost per temporary incapacity accident for more than 15 days.

(b) = Average cost per permanent disability accident

(c) = Average cost per accident due to death.

(d) = Benefit granted for temporary incapacity for more than 15 days

(e) = Benefit granted for permanent disability.

(f) = Benefit granted for death.

\section{DISCUSSION}

Based on the statistical data presented by the CNAE, the planted forests activity obtained the highest rate of accidents, which corresponded to $59.10 \%$ of the total number of accidents in 2014 , mainly due to the greater amount of labor. The activities of forest production support and natural forests accounted for $34.52 \%$ and $6.38 \%$ of the total, respectively (AEPS, 2014).

FLORESTA, Curitiba, PR, v. 47, n.4, p. 561 - 568, out/dez. 2017.

Viegas, J. G. M. et al.

ISSN eletrônico 1982-4688

DOI: $10.5380 /$ rf.v47i4.50954 
Although statistics on work accidents in the Brazilian forestry sector show a decline in the last years (2010 to 2014), the situation is worrisome if we consider that these data do not reliably portray the reality, due to factors such as the underreporting of the misfortunes that occur in the field and the increase of informal work and outsourcing. Begnini and Almeida (2015) report that, in Brazil, there is a lack of accurate information regarding the number of accidents that occur in the rural work, in addition to the fact that underreporting of accidents, especially in rural areas, is still common even though the CAT is a legal requirement.

With regard to the states with the highest number of work accidents registered in the forest activities, Minas Gerais, São Paulo, Paraná, Santa Catarina, Bahia, and Maranhão stood out as the most representative. However, a relation between this quantitative and those states that hold large areas for the planting of eucalyptus and pine in Brazil is observed. Among the states with the lowest accident rates are Rio Grande do Norte, Ceará, Alagoas, Sergipe, Acre, and Amazonas. This low incidence occurs due to the fact that these states, except Acre and Amazonas, do not have significant forest production.

Furthermore, the portrayal of accidents in the states of Acre and Amazonas shows that the data from AEPS do not reflect the reality of the region, since they are based on statistics compiled by the INSS, which binds only the formal worker. This situation results in the fragility of this information. It can be noted that, even though the formality is increasing overall, the number of informal employees is still quite high in the Northern region (MORAIS, 2007).

When comparing the numbers of work accidents and the amount of forest area, higher rates for the states of Mato Grosso do Sul, São Paulo, and Bahia are observed. On the other hand, the state of Minas Gerais, which presented the highest absolute number of work accidents recorded in forest activities, showed the lowest IAFP.

Regarding the incidence rate, we noted that the accidents in the forestry sector are worrisome, since, in the analyzed period, the activities of planted forest and forest production support presented rates higher than the Brazilian national average, which showed rates of $19.29 ; 18.23 ; 17.03 ; 16.93$ and 16.06 , respectively, for the years of 2010;2011;2012; 2013 and 2014. Thus, compared with the average of other sectors, the found rates show that the forestry segment deserves special attention with regard to work safety.

These data corroborate studies carried out by Nogueira et al. (2010), which reported that the number of accidents in the forest activities for each group of 100,000 workers, along with agriculture and hunting, was ranked sixth in terms of non-fatal accidents in Brazil.

Comparing at national level and considering the states with the greatest relevance of planted forest, work accidents in the forestry sector have a representation of $0.072 \%$. We also noticed that Social Security expenditures with benefits paid to this segment had an average cost of over R\$31 million, according to Table 4. The Minas Gerais State had the highest rate of accidents and, consequently, higher burden on the security benefits granted.

In the quantification of the costs presented in Tables 3 and 4, only those accidents whose removal of the injured occurred for more than 15 days were considered because cases of shorter duration do not result in expenses to the Social Security, since they do not offer the benefit entitlement to the insured. However, these accidents impact on productivity and generate other costs for businesses and society.

The costs of accidents demonstrate how companies need to adopt Occupational Safety and Health $(\mathrm{OSH})$ procedures and warn of the importance of practices that reduce the numbers of notifications of this nature. These events result in removals and decrease of productive capacity, interdiction of sector or machine, hiring and substitute training, negative repercussion for the image of the company, payment of compensations (material damages, moral damages and lifelong pensions) in the Labor Court, attorney's fees, lawsuits, and criminal liability of the officers.

It should be noted that the cost incurred by accidents to the companies is small when compared to the enormous suffering caused to the worker and his/her family, because nothing compares to the damage that they suffer in the form of reduction of income, discontinuance on the family employment, expenses with accommodation in other locations for treatment, as well as the physical and psychological pain of the injured.

\section{CONCLUSIONS}

- Work accidents in the forest sector are significant, and generate expenditures for Social Security due to the granting of accidental benefits. Through this research, the difficulty to obtain reliable information about work accidents in Brazil is observed, mainly due to the limitation of data obtained by DATAPREV, which is restricted only to workers governed by the CLT and disregards the uninsured, public servants and military.

- Planted forests, although small in terms of area, present more significant rates of work accidents when compared to natural forests. Assessing the indicators of work accidents in the forest area allows the observation of the historical trend and its impact on companies and workers' lives. Besides, it provides 
uninsured on the subject, favoring the determination of accident prevention programs and consequent improvement of working conditions.

\section{REFERENCES}

Anuário Estatístico da Previdência Social (AEPS ) AEPS 2014 ano base 2014. Brasília: 2016. 916 p. Disponível em: <http://mtps.gov.br/dados-abertos/dados-da-previdencia/previdencia-social-e-inss/anuario-estatistico-daprevidencia-social-aeps $\geq$ Acesso em: 21/04/2016.

ASSUNÇÃO, A. A.; CÂMARA, G. R. A precarização do trabalho e a produção de acidentes na colheita de árvores. Caderno CRH, Salvador, v. 24, n. 62, p. 385-396. 2011.

BEGNINI, S.; ALMEIDA, L. E. D. F. Acidentes de trabalho no meio rural: perfil do trabalhador acidentado em Santa Catarina, Brasil. Revista Eletrônica Gestão \& Saúde, Brasília, v. 6, n. 3, p. 2538-2552, 2015.

HECK JUNIOR, S.; OLIVEIRA, L. P. Avaliação da segurança e saúde no trabalho de operadores de motosserra na região dos Campos Gerais no estado do Paraná-Brasil. Espacios, Caracas, v. 36, n. 8, p. 11, 2015.

MEDEIROS, J. V.; JURADO, S. R. Acidentes de trabalho em madeireiras: uma revisão bibliográfica. Revista Agrogeoambiental, Pouso Alegre, v. 5, n. 2, p. 87-96, 2013.

MORAES, M. A. F. D. Indicadores do mercado de trabalho do sistema agroindustrial da cana-de-açúcar do Brasil no período 1992-2005. Estud. Econ., São Paulo,v.37, n 4, p. 875-902, 2007.

NOGUEIRA, M. M.; LENTINI, M. W.; PIRES, I. P; BITTENCOURT, P. G.; ZWEEDE, J. C. Procedimentos simplificados em segurança e saúde do trabalho no manejo florestal. Belém-PA: instituto Floresta Tropical (IFT. Manual técnico, 1), 2010, 80 p.

RICHTHOFEN, W. Inspeção do trabalho: um guia da profissão, Coimbra, Organização Internacional do Trabalho, Coimbra Editora, 2006.

Sistema Nacional de Informações Florestais - SNIF. (2016). Disponível em: <http://www.florestal.gov.br/snif/producao-florestal/cadeia-produtiva>. Acesso em: 20/04/2016. 
FLORESTA, Curitiba, PR, v. 47, n. 4, p. 561 - 568,out/dez. 2017. 